\title{
Geochemistry of Muro Banded Iron-Formation, Central Nigeria
}

\author{
John Adeyinka Adekoya, Chukwuemeka Tony Okonkwo, Mohammed Olatoye Adepoju \\ Department of Applied Geology, Federal University of Technology, Akure, Nigeria \\ Email: *yinkadekoya2002@yahoo.com; ctoo2003@yahoo.com; moadepoju@futa.edu.ng
}

Received July 13, 2012; revised August 15, 2012; accepted September 14, 2012

\begin{abstract}
Muro Banded Iron-Formation occurs in the Proterozoic Toto Schist Belt, central Nigeria. It consists preponderantly of oxide facies and minor carbonate facies. The oxide facies is made up of alternating bands of quartz (metachert) with those of hematite + magnetite + martite \pm goethite, chlorite, pyrrhotite and garnet. The carbonate facies consists of quartz (metachert) + siderite \pm goethite. In the oxide facies the total iron content $\left(\mathrm{Fe}_{2} \mathrm{O}_{3} \mathrm{t}\right)$ ranges from $33.95 \%$ to $48.08 \%$ and the $\mathrm{SiO}_{2}$ content from $50.33 \%$ to $64.50 \%$. In the case of the carbonate facies, the $\mathrm{Fe}_{2} \mathrm{O}_{3} \mathrm{t}$ content varies from $15.42 \%$ to $20.66 \%$ and $\mathrm{SiO}_{2}$ content from 66.84 to $72.86 \%$. The $\mathrm{Al}_{2} \mathrm{O}_{3}$ content is generally low ranging from $0.1 \%$ to $0.54 \%$ in the oxide facies, and $0.24 \%$ to $0.31 \%$ in the carbonate facies. Chemically, the Muro Iron-Formation is similar to the Lake Superior-type iron-formations in terms of the distribution of the major and trace elements. This taken together with similarities in lithological associations indicates its deposition in similar environments i.e. shallow intra-continental or restricted/barred marine basin. The very low $\mathrm{Al}_{2} \mathrm{O}_{3}$ contents indicate minor clastic dilution of the original chemical precipitates.
\end{abstract}

Keywords: Muro Iron-Formation; Oxide Facies; Carbonate Facies; Geochemistry; Central Nigeria

\section{Introduction}

Muro Banded Iron-Formation (BIF) is one of the banded iron-formations (BIFs) associated with the Proterozoic metasedimentary "schist belts" in northern Nigeria (Figure 1). The BIF and associated metasediments form a range of elongate but rugged Muro Hills stretching for 13 $\mathrm{km}$ in a NE-SW direction. Two facies of the BIF, namely, oxide and carbonate facies [1] have been recognised with the former predominating and the latter being poorly developed and rather sporadic [2].

Since the discovery of the iron deposit by the Geological Survey of Nigeria in 1981, only reconnaissance studies have been done on its geological and structural setting as well as its geochemistry [3-6]. The present investigation is aimed at studying in some detail the geochemical characteristics of the iron-formation. Bulk chemical analysis of the iron-bearing rocks was carried out, and major and trace element contents of the BIF were compared with those of other Nigerian and Lake Superior-type and Algoma-type BIFs.

\section{Geological Setting}

\subsection{Regional Geology}

The Muro Banded Iron-Formation occurs in the Toto

"Corresponding author.
Schist Belt which is part of the Proterozoic supracrustal assemblage in the Nigerian basement complex [7]. The Nigerian basement is the southern part of Neoproterozoic Pan-African mobile belt situated east of the West African

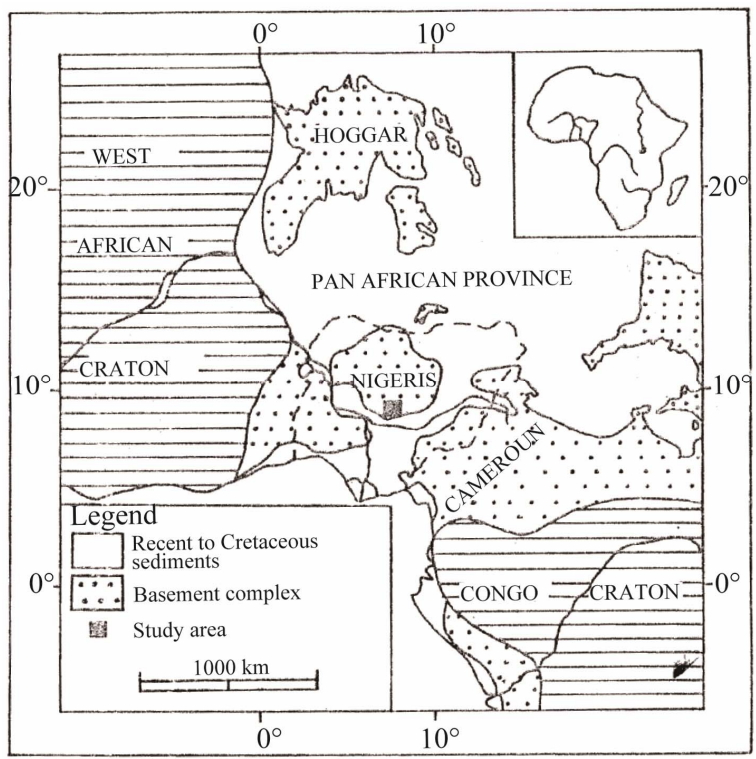

Figure 1. Index map showing the location of the Muro District in the Pan-African province in relation to the West African and the Congo cratons. 
craton. Most of the supracrustals forming the schist belts in Nigeria are exposed predominantly west of longitude $8^{\circ}$. The age of the metasediments is uncertain as both Paleoproterozoic and Neoproterozoic ages have been obtained from them. In general, they bear imprints of polyphase deformation (D1 - D4) and metamorphism [8]. They consist essentially of pelitic and semi-pelitic schists and phyllites interlayered with minor to substantial quartzites, metaconglomerate, iron-formation, marble and amphibolites of tholeiitic affinity. The main deformation phase (D2) produced major folds such as the Muro antiform in the study area.

Both the basement and its supracrustal cover (the Schist Belts) have been intruded by a suite of Pan-African granites (Older Granites) with minor contact metamorphic and local migmatisation effects in the host rocks during the Pan African orogeny (ca $600 \pm 150 \mathrm{Ma}$ ).

\subsection{Local Geology of Muro Area}

Four major lithological units which are interbanded have been mapped in the Muro area (Figure 2). These include marble, banded iron-formation, quartzites, and metasediments of pelitic to semi-pelitic composition. The various lithologies are folded into an overturned antiform trending NE-SW [4]. The marble occupies both the innermost core (M1) and flanks (M2) of the fold.

Successively following the former are bands of pelitic and semi-pelitic metasediments, quartzites and banded iron-formation. West of the Muro Hills, the metasedi- ments are unconformably overlain by the Cretaceous Nupe Sandstone.

Bands of iron-formation (35 - 100 m wide/thick) occur between the outer zone marble and the quartzites. They outcrop in elongate ridges and irregular hills which take the arcuate form of the Muro Antiform (Figure 2) and can be traced for $20 \mathrm{~km}$. Two generations of minor folds are exhibited in the iron-formation. These include tight, isoclinal, overturned folds having attenuated limbs with thickened or sharp crests and open folds with nearly horizontal axes. Both oxide and carbonate facies [1,9] occur but the former predominates with the latter being poorly developed. Occasionally bands of jasper are associated with the iron-formation.

The oxide facies iron-formation is a dark grey, finegrained, crystalline rock which displays banding on both centimetric and millimetric scales (i.e. meso- and microbanding). The banding consists of alternating light-coloured quartz-rich and darker-coloured iron oxide-rich layers. The mesobands range in width from about $1 \mathrm{~cm}$ to 2 $\mathrm{cm}$ (Figure 3) and the microbands from $<0.5-2 \mathrm{~mm}$ (Figure 4).

The carbonate facies is a very hard, fine grained, massive rock made up of irregular brown siderite-rich and metachert-rich portions (Figure 5). It commonly occurs as rubble or vuggy boulders as found at west of Kuttiko in the southern area of the Muro Hills. Banding which is characteristic of the oxide facies is either non-existent or rare in this rock.

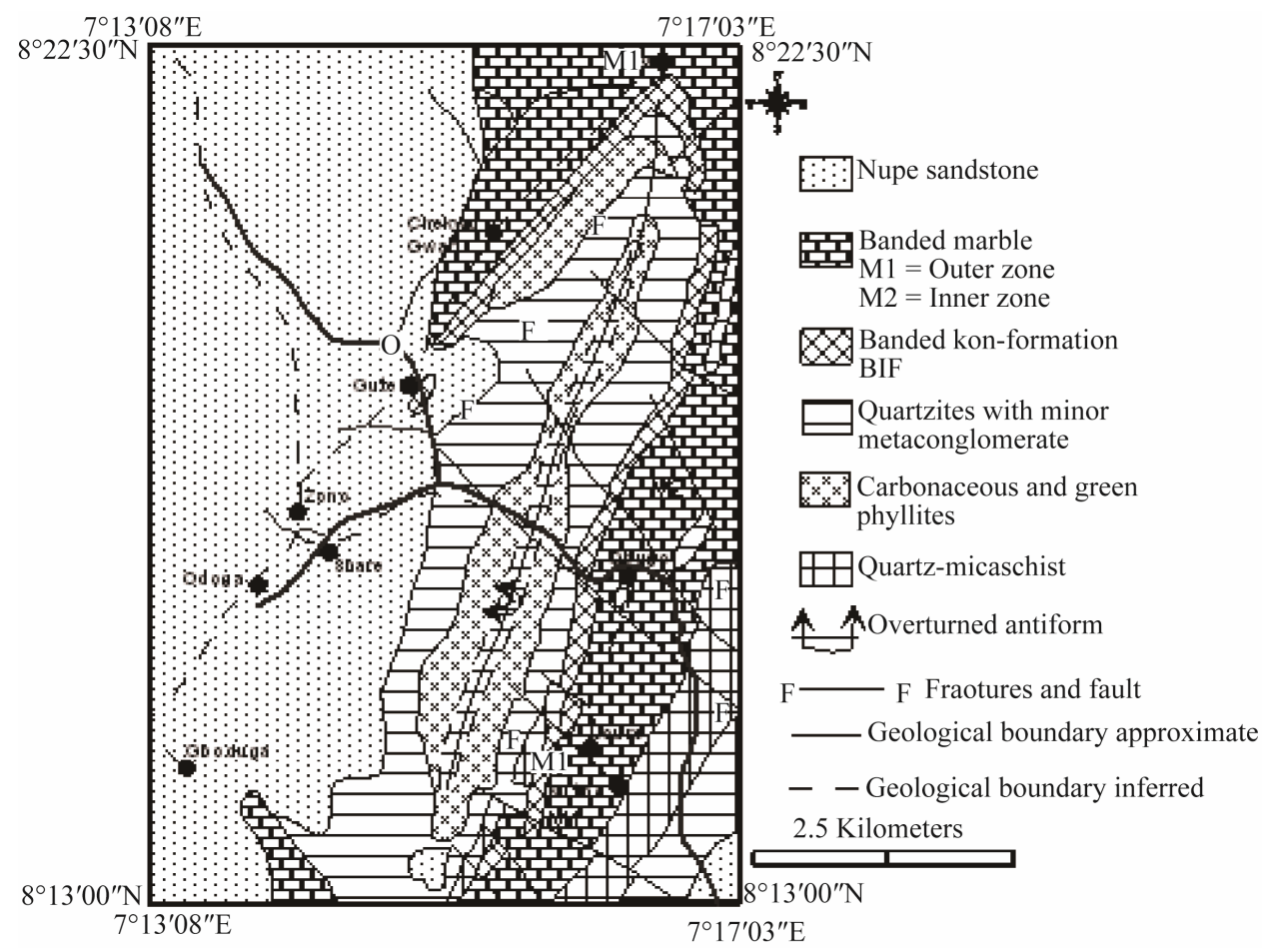

Figure 2. Geological map of Muro district, central Nigeria. 


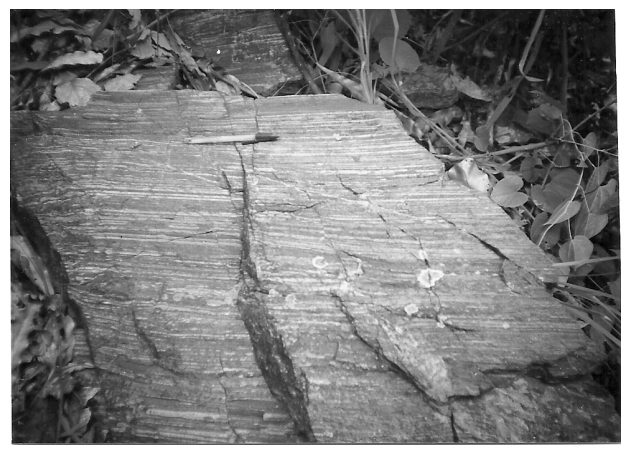

Figure 3. Photograph of Muro iron-formation oxide facies displaying dark iron-rich mesobands interbanded with lightcoloured quartz-rich ones.

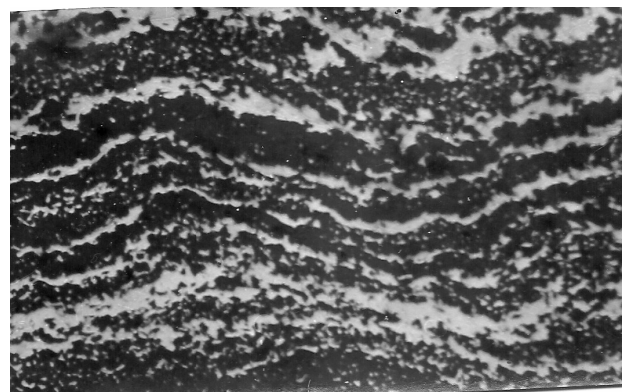

Figure 4. Photomicrograph of polished section of the oxide facies of the Muro iron-formation displaying grey, hematite-rich microbands alternating with dark, quartz-rich ones. Reflected light; Magnification $\times 20$.

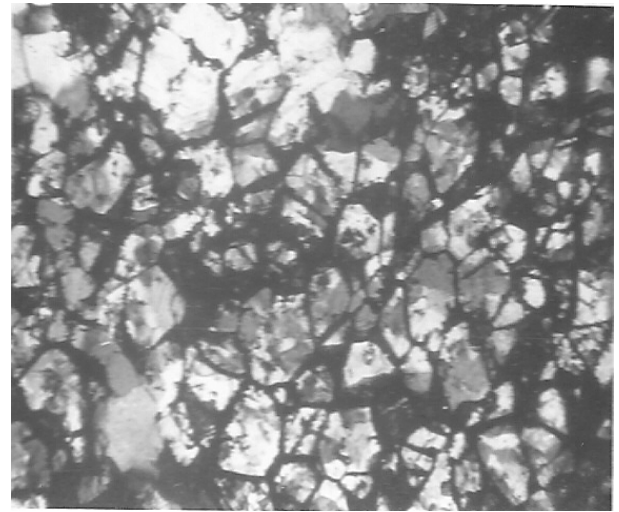

Figure 5. Photomicrograph of carbonate facies iron-formation showing siderite grains oxidized to black iron oxides at grain boundaries. Transmitted light;crossed polars; Magnification $\times 25$.

\section{Analytical Methods}

Representative samples of the two facies of the BIF were selected and analysed for both major and trace elements using a Phillips PW 1450 automatic sequential X-ray fluorescence (XRF) in the Department of Geological Sciences, McGill University, Montreal, Canada. Analyses were done on the fused beads for $\mathrm{SiO}_{2}, \mathrm{TiO}_{2}, \mathrm{Al}_{2} \mathrm{O}_{3}$, $\mathrm{Fe}_{2} \mathrm{O}_{3}, \mathrm{MnO}, \mathrm{MgO}, \mathrm{CaO}, \mathrm{Na}_{2} \mathrm{O} \mathrm{K}{ }_{2} \mathrm{O}, \mathrm{P}_{2} \mathrm{O}_{5}, \mathrm{Ba}, \mathrm{Cr}, \mathrm{Ni}, \mathrm{V}$ and $\mathrm{Zn}$. Other trace elements- $\mathrm{Nb}, \mathrm{Pb}, \mathrm{Rb}, \mathrm{Th}, \mathrm{Sr}, \mathrm{Cu}$, $\mathrm{Co}, \mathrm{U}, \mathrm{Y}$ and $\mathrm{Zr}$ - were analysed on pressed rock powder pellets by XRF spectrometry. The loss on ignition (LOI) of each rock powder was calculated after igniting to a constant weight.

\section{Results and Discussion}

\subsection{Major Element Geochemistry}

Geochemical analyses (Table 1) have revealed the essentially bimodal composition of the iron-formation with silica $\left(\mathrm{SiO}_{2}\right)$ and total iron $\left(\right.$ as $\left.\mathrm{Fe}_{2} \mathrm{O}_{3} \mathrm{t}\right)$ constituting over $85 \%$ of its components irrespective of the facies. Other components except the volatiles (LOI) occur in very small amounts. An antithetic relationship exists between the $\mathrm{SiO}_{2}$ and total $\mathrm{Fe}_{2} \mathrm{O}_{3}$, which is reflected in the strong negative correlation between the two components (Figure 6) and in the empirical inverse distribution of quartz and iron minerals in the iron-formation. In this respect Muro iron-formation is similar to iron-formations in other parts of the world [10-12]. A plot of the Muro samples in the compositional diagram after [10] shows that they lie in the Precambrian BIF field (Figure 7), thus indicating that the Muro BIF is geochemically similar to other Precambrian iron-formations.

Silica $\left(\mathrm{SiO}_{2}\right)$ content in the oxide facies ranges from $50.33 \%-64.50 \%$ with an average of $56.53 \%$. Higher values obtained from the carbonate facies samples could be due to highly irregular distribution of the metachert and siderite and the difficulty in obtaining representative samples on the field. However, the generally high silica contents in all the BIF samples are attributable largely to the high metachert or quartz constituents of the iron-formation.

$\mathrm{TiO}_{2}$ content $(0.01 \%-0.05 \%)$ is very low with essentially uniform distribution as most samples are in the range of $0.01 \%-0.02 \%$ (Table 1). Alumina content is low, ranging from $0.01 \%-0.54 \%$ with an average of $0.28 \%$ for either the oxide or carbonate facies. In spite of the low concentration of alumina, it exhibits a weak positive correlation with $\mathrm{TiO}_{2}$ (Figure 8). This is probably inherited from the common association of $\mathrm{Ti}$ and $\mathrm{Al}$ in clayey materials derived from residual weathering products. Both $\mathrm{Al}$ and $\mathrm{Ti}$ are hydrolysate elements [13] which are transported together by rivers to the basin of deposition [14]. The presence of clay material in the iron-formation of which alumina is an index indicates an initial clastic dilution in the basin of deposition.

Total iron as $\mathrm{Fe}_{2} \mathrm{O}_{3}$ ranges from $33.15 \%$ to $48.08 \%$, with an average of $41.69 \%$, in the oxide facies. The iron content of the carbonate facies is extremely variable and its total iron content $\left(\mathrm{Fe}_{2} \mathrm{O}_{3} \mathrm{t}\right)$ ranges from $3.68 \%$ $20.66 \%$. The relatively low values of iron in this facies are attributable to the same factors that accounted for its 
Table 1. Major element concentrations of the oxide facies (1 - 13) and the carbonate facies (14 - 18) of the Muro Banded iron-formation.

\begin{tabular}{|c|c|c|c|c|c|c|c|c|c|c|c|c|c|c|c|c|c|c|}
\hline \multirow{2}{*}{ Element - } & 1 & 2 & 3 & 4 & 5 & 6 & 7 & 8 & 9 & 10 & 11 & 12 & 13 & 14 & 15 & 16 & 17 & 18 \\
\hline & \multicolumn{13}{|c|}{ Oxide Facies } & \multicolumn{5}{|c|}{ Carbonate Facies } \\
\hline $\mathrm{SiO}_{2}$ & 59.41 & 53 & 53.01 & 56.23 & 63.27 & 50.33 & 63.64 & 58.73 & 55.54 & 54.06 & 51.05 & 62.18 & 64.5 & 93.87 & 70.47 & 66.54 & 72.86 & 68.39 \\
\hline $\mathrm{TiO}_{2}$ & 0.01 & 0.05 & 0.02 & 0.02 & 0.01 & 0.01 & 0.05 & 0.02 & 0.04 & 0.02 & 0.01 & 0.01 & 0.01 & 0.01 & 0.01 & 0.04 & 0.01 & 0.01 \\
\hline $\mathrm{Al}_{2} \mathrm{O}_{3}$ & 0.18 & 0.21 & 0.37 & 0.41 & 0.09 & 0.1 & 0.54 & 0.19 & 0.45 & 0.41 & 0.01 & 0.2 & 0.49 & 0.27 & 0.24 & 0.25 & 0.28 & 0.31 \\
\hline $\mathrm{Fe}_{2} \mathrm{O}_{3}$ & ND & 36.58 & ND & ND & ND & 47.72 & 33.38 & 35.94 & 36.56 & 36.37 & 46.95 & 36.27 & 32.41 & 3.68 & 1.58 & 3.72 & 1.49 & 2.13 \\
\hline $\mathrm{FeO}$ & ND & 8.47 & ND & ND & ND & 0.23 & 0.19 & 4.87 & 7.85 & 8.04 & 1.02 & 0.63 & 0.67 & ND & 14.32 & 15.13 & 12.54 & 16.68 \\
\hline $\mathrm{Fe}_{2} \mathrm{O}_{3} \mathrm{t}$ & 40.04 & 45.99 & 45.9 & 42.62 & 35.7 & 47.98 & 33.59 & 41.35 & 45.28 & 45.3 & 48.08 & 36.97 & 3.15 & 3.68 & 17.49 & 20.53 & 15.42 & 20.66 \\
\hline $\mathrm{MnO}$ & 0.08 & 0.05 & 0.08 & 0.03 & 0.04 & 0.06 & 0.12 & 0.06 & 0.05 & 0.03 & 0.04 & 0.07 & 0.1 & 1.06 & 2.75 & & & \\
\hline $\mathrm{MgO}$ & 0.01 & 0.06 & 0.05 & 0.01 & 0.01 & 0.01 & 0.01 & 0.01 & 0.01 & 0.02 & 0.01 & 0.01 & 0.01 & 0.02 & 0.01 & 0.02 & 0.03 & 0.05 \\
\hline $\mathrm{CaO}$ & 0.02 & 0.01 & 0.01 & 0.04 & 0.01 & 0.1 & 0.01 & 0.05 & 0.03 & 0.01 & 0.01 & 0.01 & 0.01 & 0.06 & 0.08 & 0.11 & 0.07 & 0.06 \\
\hline $\mathrm{Na}_{2} \mathrm{O}$ & 0.01 & 0.01 & 0.01 & 0.01 & 0.01 & 0.01 & 0.01 & 0.01 & 0.01 & 0.01 & 0.01 & 0.01 & 0.01 & 0.01 & 0.01 & 0.01 & 0.01 & 0.01 \\
\hline $\mathrm{K}_{2} \mathrm{O}$ & 0.01 & 0.07 & 0.03 & 0.07 & 0.01 & 0.01 & 0.01 & 0.01 & 0.04 & 0.02 & 0.01 & 0.01 & 0.01 & 0.03 & 0.05 & 0.08 & 0.03 & 0.04 \\
\hline $\mathrm{P}_{2} \mathrm{O}_{5}$ & 0.023 & 0.05 & 0.046 & 0.009 & 0.035 & 0.15 & 0.042 & 0.03 & 0.01 & 0.03 & 0.13 & 0.04 & 0.05 & 0.14 & 0.16 & 0.27 & 0.18 & 0.2 \\
\hline LOI & 0.13 & 0.57 & 0.51 & 0.01 & 0.72 & 1.45 & 2.07 & 0.52 & 0.1 & 0.72 & 0.77 & 0.83 & 2.14 & 1.25 & 11.21 & 10.97 & 11 & 10.06 \\
\hline Total & 99.89 & 99.12 & 100.03 & 99.44 & 99.87 & 100.14 & 100.04 & 100.41 & 100.67 & 99.73 & 99.98 & 100.24 & 100.51 & 100.39 & 100.88 & 100.22 & 100.41 & 100.26 \\
\hline Total Fe & 28 & 32.17 & 32.1 & 29.81 & 24.97 & 33.56 & 23.49 & 28.92 & 31.67 & 31.68 & 33.63 & 25.86 & 23.18 & 2.57 & 12.23 & 14.36 & 10.78 & 14.45 \\
\hline $\begin{array}{l}\mathrm{SiO}_{2} / \\
\mathrm{Fe}_{2} \mathrm{O}_{3}\end{array}$ & 1.5 & 1.2 & 1.2 & 1.3 & 1.8 & 1.1 & 1.9 & 1.42 & 1.23 & 1.19 & 1.06 & 1.68 & 1.95 & 25.5 & 4.03 & 3.24 & 4.72 & 3.31 \\
\hline $\begin{array}{c}\mathrm{Al}_{2} \mathrm{O}_{3} / \\
\mathrm{SiO}_{2}\end{array}$ & 0.0030 & 0.0040 & 0.0069 & 0.0073 & 30.0014 & 0.0020 & 0.0085 & 0.0032 & 0.0081 & 0.0075 & 0.00019 & 0.0032 & 0.0076 & 0.0029 & 0.0034 & 0.0038 & 0.0038 & 0.0045 \\
\hline
\end{tabular}

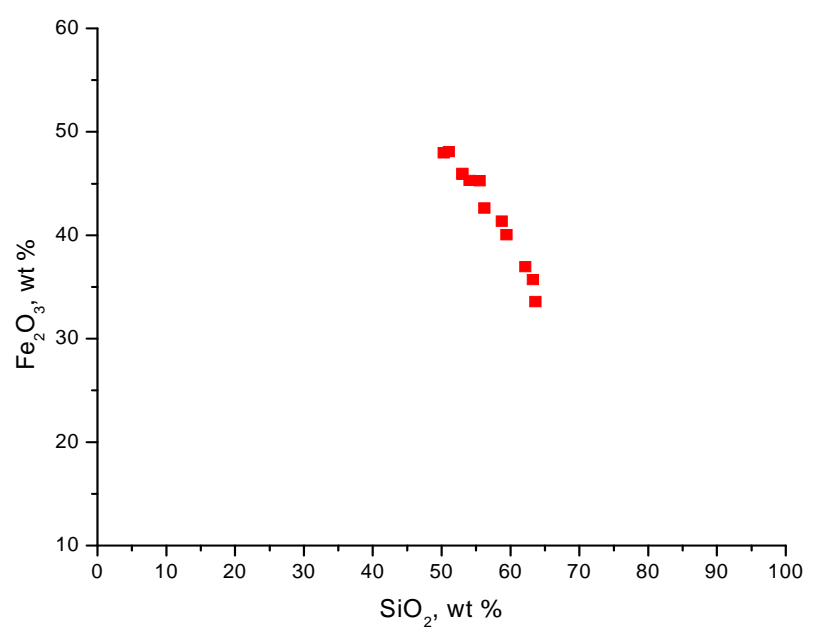

Figure 6. Plot of $\mathrm{SiO}_{2}$ against $\mathrm{Fe}_{2} \mathrm{O}_{3}$ for the Muro oxide facies showing a negative correlation between silicon and iron.

very high $\mathrm{SiO}_{2}$ values as explained above. Chemical analyses (Table 1) have revealed high $\mathrm{Fe}_{2} \mathrm{O}_{3}$ and low $\mathrm{FeO}$ values in the oxide facies in consonance with the preponderant hematite and subordinate magnetite in the

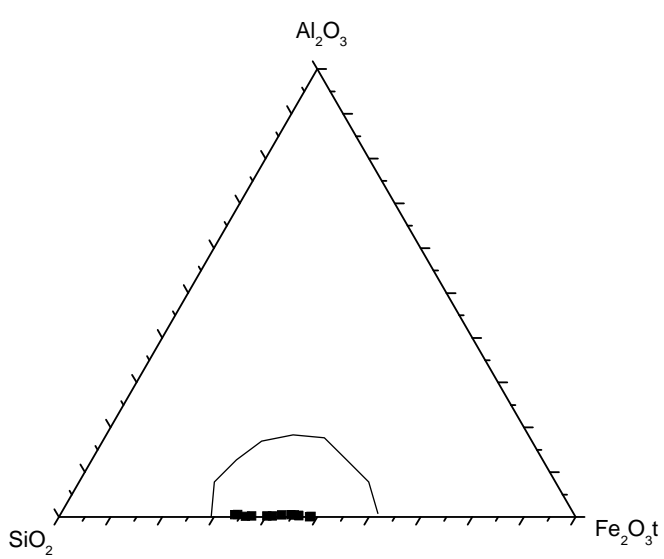

Figure 7. $\mathrm{Al}_{2} \mathrm{O}_{3}-\mathrm{SiO}_{2}-\mathrm{Fe}_{2} \mathrm{O}_{3} \mathrm{t}$ triangular diagram showing the field of Precambrian Banded iron-formations (BIF) after Govett (1966) and the plots of the Muro oxide facies samples correlation between the two elements.

rock. Similarly, the carbonate facies contains relatively high $\mathrm{FeO}$ and low $\mathrm{Fe}_{2} \mathrm{O}_{3}$ components, thus reflecting the presence of siderite as the main mineral in that facies.

Manganese content is low (mean 0.06\%) and is distributed somewhat uniformly in the oxide facies but it is 




Figure 8. Plot of $\mathrm{Al}_{2} \mathrm{O}_{3}$ against $\mathrm{TiO}_{2}$ for the Muro oxide facies showing some positive correlation albeit with some scatter.

much higher (mean 2.23\%) in the carbonate facies.

Very low concentrations of magnesium and calcium are present in the iron-formation irrespective of its facies. $\mathrm{MgO}$ content ranges from $0.01 \%-0.06 \%$ and $\mathrm{CaO}$ content from $0.01 \%-0.11 \%$. The low concentrations of the two elements especially when combined with the low volatile contents (LOI) of the oxide facies indicate paucity of carbonate and silicate minerals in the facies [15], which is also confirmed from petrographic studies.

The alkali metal contents $\left(\mathrm{Na}_{2} \mathrm{O}\right.$ and $\left.\mathrm{K}_{2} \mathrm{O}\right)$ are very low with most samples having values of $0.01 \%$ especially in the case of sodium. This also reflects the rarity of silicate minerals in the iron deposit.
Phosphorous content $\left(\mathrm{P}_{2} \mathrm{O}_{5}\right)$ is low varying from 0.01 $\%-0.27 \%$ in the iron-formation. Its distribution tends to be uniform in the oxide facies which also displays much lower concentration (average $0.05 \%$ ) than the carbonate facies (average $0.19 \%$ ).

Compared with the data from [16] and [12] the mean contents of $\mathrm{Fe}_{2} \mathrm{O}_{3}, \mathrm{TiO}_{2}, \mathrm{MnO}, \mathrm{MgO}, \mathrm{CaO}, \mathrm{Na}_{2} \mathrm{O}, \mathrm{K}_{2} \mathrm{O}$, $\mathrm{P}_{2} \mathrm{O}_{5}$ and $\mathrm{Al}_{2} \mathrm{O}_{3}$ in the Muro oxide facies are similar to those of the Lake Superior and the Algoma oxide facies (Figure 9, Table 2). However, the Muro oxide facies has a slightly higher $\mathrm{SiO}_{2}$ content relative to the others (Figure 9).

\subsection{Trace Element Geochemistry}

The trace elements presented in Table $\mathbf{3}$ are expressed in averages and ranges in Table 4 for comparison with the average trace element contents of other iron-formations. The low values of these elements in the Muro Iron-Formation are similar to their values in Precambrian ironformations in other parts of the world [12,15,17-19].

Its oxide facies (Table 3, analyses 1 - 13) appears to be more impoverished in trace elements than the carbonate facies (analyses 14 - 18) which contains relatively high concentrations of $\mathrm{Ba}, \mathrm{Cu}, \mathrm{Ni}, \mathrm{Mn}, \mathrm{Co}$, and $\mathrm{V}$ compared with even the Lake Superior-type and Algoma-type BIFs (Table 4). Occurring in particularly low concentrations (lower than the detection limits of the analytical instrument) are $\mathrm{Ni}, \mathrm{Rb}, \mathrm{Y}$ and $\mathrm{Zn}$ in the oxide facies and $\mathrm{Rb}$ and $\mathrm{Zn}$ in the carbonate facies (Table 3).

In general, the level of trace element concentrations in the Muro oxide facies is less than those of its Lake Superior-type and Algoma-type BIFs (Table 4, Figure 10).

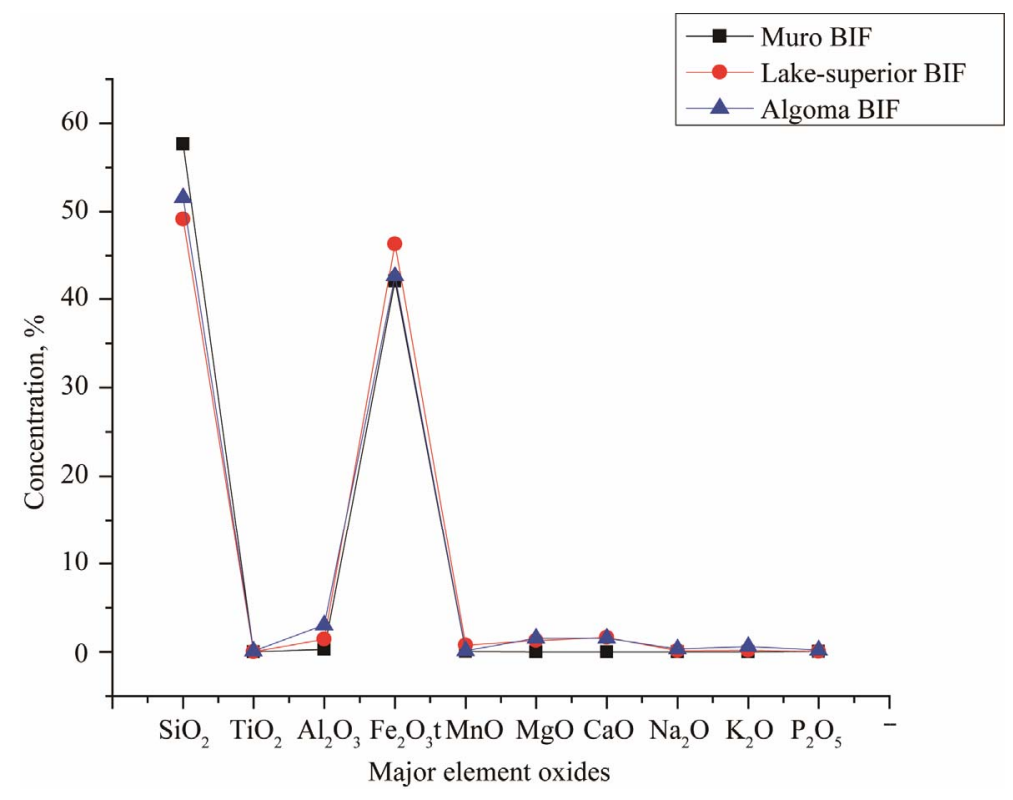

Figure 9. Spider diagram comparing the major element composition of Muro BIF with those of Lake Superior-type and Algoma-type BIFs. 
Table 2. Major element summary statistics (range, mean and number of samples, $\mathbf{n}$ ) of Muro Iron-Formation and some other iron-formations from different parts of the world.

\begin{tabular}{|c|c|c|c|c|c|c|c|c|c|c|c|c|}
\hline & \multicolumn{2}{|c|}{$\begin{array}{l}\text { Muro Iron-Formation } \\
\mathrm{n}=13\end{array}$} & \multicolumn{2}{|c|}{$\begin{array}{l}\text { Yilgarn Block, } \\
\text { Australia } \\
\text { n = 35 }\end{array}$} & \multicolumn{2}{|c|}{$\begin{array}{c}\text { Brockman } \\
\text { Iron-Formation } \\
\mathrm{n}=10\end{array}$} & \multicolumn{2}{|c|}{$\begin{array}{c}\text { Biwabik } \\
\text { Iron-Formation } \\
\mathrm{n}=7\end{array}$} & \multicolumn{2}{|c|}{$\begin{array}{c}\text { Lake } \\
\text { Superior-Type } \\
\text { Mean }\end{array}$} & \multicolumn{2}{|c|}{$\begin{array}{l}\text { Algoma-Type } \\
\text { Mean }\end{array}$} \\
\hline & Range & Mean & Range & Mean & Range & Mean & Range & Mean & Oxide & Silicate & Oxide & Silicate \\
\hline $\mathrm{SiO}_{2}$ & $51.00-64.96$ & 57.66 & $21.53-68.28$ & 49.07 & $43.44-60.21$ & 48.2 & $46.93-53.96$ & 50.62 & 49.13 & 63.38 & 51.58 & 48.62 \\
\hline $\mathrm{TiO}_{2}$ & $0.01-0.05$ & 0.02 & $0.00-0.18$ & & $0.01-0.07$ & 0.03 & $0.22-0.13$ & 0.06 & 0.02 & 0.2 & 0.09 & 0.2 \\
\hline $\mathrm{Al}_{2} \mathrm{O}_{3}$ & $0.09-0.55$ & 0.28 & $0.01-3.51$ & 0.7 & $0.13-1.22$ & 0.47 & $0.33-2.28$ & 1.13 & 1.45 & 2.59 & 3.06 & 7.96 \\
\hline $\mathrm{Fe}_{2} \mathrm{O}_{3}$ & 34.07 - 48.62 & 38.29 & 1.98 - 37.55 & 18.98 & 17.99 - 35.91 & 29.09 & $12.00-26.25$ & 20.28 & 36.84 & 9.35 & 27.43 & 16.63 \\
\hline $\mathrm{FeO}$ & $0.20-8.60$ & 3.58 & $14.37-66.61$ & 23.65 & $13.32-19.64$ & 16.49 & $17.44-26.65$ & 21.43 & 8.54 & 17.51 & 13.26 & 19.05 \\
\hline $\mathrm{Fe}_{2} \mathrm{O}_{3} \mathrm{t}$ & 38.71 - 48.62 & 42.02 & ND & & ND & 47.41 & ND & 44.09 & 46.33 & 28.81 & 42.62 & 37.8 \\
\hline $\mathrm{MnO}$ & $0.03-0.12$ & 0.06 & $0.04-2.76$ & 0.55 & $0.00-0.27$ & 0.08 & $0.41-1.02$ & 0.72 & 0.76 & 0.37 & 0.14 & 0.77 \\
\hline $\mathrm{MgO}$ & $0.01-0.06$ & 0.01 & $1.00-9.63$ & 3.46 & $1.70-3.70$ & 2.39 & $2.59-4.08$ & 3.17 & 1.29 & 2.93 & 1.56 & 3.04 \\
\hline $\mathrm{CaO}$ & $0.01-0.10$ & 0.02 & $0.32-7.61$ & 2.68 & $0.05-3.80$ & 1.81 & $1.02-3.17$ & 1.98 & 1.64 & 2.58 & 1.54 & 3.04 \\
\hline $\mathrm{Na}_{2} \mathrm{O}$ & $0.01-0.01$ & 0.01 & $0.02-0.57$ & 0.11 & $0.03-1.33$ & 0.49 & $0.02-0.09$ & 0.06 & 0.12 & 0.21 & 0.32 & 0.05 \\
\hline $\mathrm{K}_{2} \mathrm{O}$ & $0.01-0.07$ & 0.02 & $0.00-0.61$ & & $0.11-2.85$ & 0.71 & $0.07-0.31$ & 0.17 & 0.15 & 0.68 & 0.59 & 0.43 \\
\hline $\mathrm{P}_{2} \mathrm{O}_{5}$ & $0.01-0.15$ & 0.05 & $0.02-0.45$ & 0.16 & $0.22-0.49$ & 0.22 & $0.05-0.17$ & 0.09 & 0.06 & 0.11 & 0.21 & 0.44 \\
\hline $\mathrm{S}$ & ND & ND & ND & $0-5.20$ & $0-0.06$ & 0.03 & ND & & 0.02 & 0.09 & 0.30 & 1.95 \\
\hline$-\mathrm{O}=\mathrm{S}$ & ND & ND & ND & ND & ND & 0.09 & ND & & ND & ND & ND & ND \\
\hline Total & & 100 & & 100 & & 100 & & 99.71 & 100 & 100 & 100 & 100 \\
\hline
\end{tabular}

Table 3. Trace element concentrations of the oxide facies $(1-13)$ and the carbonate facies (14 - 18) of the Muro Banded Iron-Formation.

\begin{tabular}{|c|c|c|c|c|c|c|c|c|c|c|c|c|c|c|c|c|c|c|}
\hline \multirow{2}{*}{ Element- } & 1 & 2 & 3 & 4 & 5 & 6 & 7 & 8 & 9 & 10 & 11 & 12 & 13 & 14 & 15 & 16 & 17 & 18 \\
\hline & \multicolumn{13}{|c|}{ Oxide Facies } & \multicolumn{5}{|c|}{ Carbonate Facies } \\
\hline V & 10 & 14 & 21 & 10 & 12 & 10 & 17 & 10 & 19 & 23 & 10 & 14 & 22 & 112 & 98 & 102 & 80 & 110 \\
\hline $\mathrm{Cr}_{2} \mathrm{O}_{3}$ & $\begin{array}{c}15 \\
(10)\end{array}$ & $\begin{array}{c}15 \\
(10)\end{array}$ & $\begin{array}{c}28 \\
(19)\end{array}$ & $\begin{array}{c}15 \\
(10)\end{array}$ & $\begin{array}{c}15 \\
(10)\end{array}$ & $\begin{array}{c}15 \\
(10)\end{array}$ & $\begin{array}{c}15 \\
(10)\end{array}$ & $\begin{array}{c}15 \\
(10)\end{array}$ & $\begin{array}{c}15 \\
(10)\end{array}$ & $\begin{array}{c}15 \\
(10)\end{array}$ & $\begin{array}{c}15 \\
(10)\end{array}$ & $\begin{array}{c}15 \\
(10)\end{array}$ & $\begin{array}{c}30 \\
(21)\end{array}$ & $\begin{array}{c}33 \\
(23)\end{array}$ & $\begin{array}{c}35 \\
(24)\end{array}$ & $\begin{array}{c}28 \\
(19)\end{array}$ & $\begin{array}{c}18 \\
(12)\end{array}$ & $\begin{array}{c}32 \\
\text { (22) }\end{array}$ \\
\hline Co & ND & 194 & ND & ND & ND & 189 & 142 & 170 & 154 & 195 & 140 & 180 & 130 & 154 & 148 & 150 & 130 & 128 \\
\hline $\mathrm{Ni}$ & 10 & 10 & 10 & 10 & 10 & 10 & 10 & 10 & 10 & 10 & 10 & 10 & 10 & 10 & 10 & 22 & 26 & 17 \\
\hline $\mathrm{Cu}$ & 14 & 10 & 10 & 10 & 264 & 32 & 10 & 10 & 10 & 170 & 28 & 18 & 10 & 357 & 208 & 299 & 345 & 313 \\
\hline $\mathrm{Zn}$ & 10 & 10 & 10 & 10 & 10 & 10 & 10 & 10 & 10 & 10 & 10 & 10 & 10 & 10 & 10 & 10 & 10 & 10 \\
\hline $\mathrm{Nb}$ & 5 & 5 & 5 & 7 & 6 & 5 & 7 & 5 & 5 & 6 & 7 & 5 & 6 & 8 & 8 & 7 & 8 & 6 \\
\hline $\mathrm{Zr}$ & 44 & 39 & 41 & 39 & 38 & 38 & 40 & 38 & 40 & 39 & 42 & 36 & 38 & 43 & 40 & 42 & 44 & 43 \\
\hline $\mathrm{Y}$ & 5 & 5 & 5 & 5 & 5 & 5 & 5 & 5 & 5 & 5 & 5 & 5 & 5 & 5 & 45 & 5 & 5 & 5 \\
\hline $\mathrm{Sr}$ & 19 & 20 & 17 & 20 & 18 & 17 & 19 & 18 & 16 & 17 & 19 & 20 & 19 & 36 & 34 & 35 & 38 & 37 \\
\hline $\mathrm{Rb}$ & 5 & 5 & 5 & 5 & 5 & 5 & 5 & 5 & 5 & 5 & 5 & 5 & 5 & 5 & 5 & 5 & 5 & 5 \\
\hline $\mathrm{Pb}$ & 5 & 16 & 6 & 10 & 6 & 5 & 8 & 5 & 16 & 12 & 10 & 5 & 6 & 5 & 5 & 6 & 8 & 5 \\
\hline Th & 5 & 12 & 5 & 6 & 5 & 5 & 5 & 5 & 5 & 6 & 10 & 5 & 5 & 5 & 5 & 5 & 5 & 5 \\
\hline $\mathrm{U}$ & 10 & 12 & 8 & 6 & 9 & 12 & 7 & 8 & 6 & 9 & 10 & 8 & 7 & 9 & 9 & 10 & 8 & 6 \\
\hline
\end{tabular}


Table 4. Trace element summary statistics (range, mean and number of samples, $n$ ) of Muro Iron-Formation and mean of some other iron-formations from different parts of the world.

\begin{tabular}{ccccccccccc}
\hline & $\begin{array}{c}\text { Muro Oxide Facies } \\
\text { N }=13\end{array}$ & \multicolumn{2}{c}{$\begin{array}{c}\text { Muro Carbonate } \\
\text { Facies }\end{array}$} & $\begin{array}{c}\text { Lake Superior } \\
\text { Oxide Facies }\end{array}$ & $\begin{array}{c}\text { Lake Superior } \\
\text { Silicate Facies }\end{array}$ & $\begin{array}{c}\text { Algoma } \\
\text { Oxide Facies }\end{array}$ & $\begin{array}{c}\text { Algoma } \\
\text { Silicate Facies }\end{array}$ & $\begin{array}{c}\text { Orissa } \\
\text { Oxide Facies }\end{array}$ & $\begin{array}{c}\text { Minas } \\
\text { Gerais Itabirite }\end{array}$ \\
\cline { 2 - 11 } & Range & Mean & Range & Mean & Mean & Mean & Mean & Mean & Mean & Mean \\
\hline $\mathrm{Ba}$ & $<9-99$ & 41 & $614-1144$ & 924 & 180 & 170 & 170 & 70 & 10 & 179 \\
$\mathrm{Co}$ & $142-194$ & 166 & $128-154$ & 142 & 27 & 27 & 38 & 36 & $<10$ & 69 \\
$\mathrm{Cr}$ & $<10-19$ & 10 & $12-24$ & 20 & 122 & 102 & 78 & 38 & 30 & 28.5 \\
$\mathrm{Cu}$ & $<10-264$ & 40 & $208-357$ & 304 & 10 & 37 & 96 & 99 & 10 & 22 \\
$\mathrm{Mn}$ & $232-264$ & 465 & $8200-23900$ & 17300 & 4600 & 3400 & 1400 & 7300 & 120 & 1785 \\
$\mathrm{Nb}$ & $<5-7$ & 5 & $6-8$ & 7 & ND & ND & ND & ND & ND & ND \\
$\mathrm{Ni}$ & $<10$ & $<10$ & $17-26$ & 22 & 32 & 46 & 83 & 151 & 15 & 20.5 \\
$\mathrm{~Pb}$ & $<5-16$ & 8 & $<5-8$ & 5 & ND & ND & ND & ND & ND & ND \\
$\mathrm{Rb}$ & $<5$ & $<5$ & $<5$ & $<5$ & ND & ND & ND & ND & ND & ND \\
$\mathrm{Sr}$ & $16-20$ & 18 & $34-37$ & 36 & 42 & 30 & 98 & 23 & 15 & ND \\
$\mathrm{Th}$ & $<5-12$ & 5 & $<5-5$ & 5 & ND & ND & ND & ND & ND & ND \\
$\mathrm{Ti}$ & $60-300$ & 120 & $<60-240$ & 60 & 160 & 1900 & 860 & 1910 & 40 & 216.6 \\
$\mathrm{U}$ & $6-12$ & 9 & $6-10$ & 8 & ND & ND & ND & ND & ND & ND \\
$\mathrm{V}$ & $10-23$ & 12 & $80-112$ & 100 & 30 & 124 & 97 & 54 & 30 & 35 \\
$\mathrm{Y}$ & $<5$ & $<5$ & $<5-45$ & 8 & 41 & 43 & 54 & 34 & ND & ND \\
$\mathrm{Zn}$ & $<10$ & $<10$ & $<10$ & $<10$ & 2 & ND & 33 & 34 & ND & ND \\
$\mathrm{Zr}$ & $36-41$ & 39 & $40-43$ & 42 & 56 & 165 & 84 & 267 & 10 & 17.3 \\
\hline & & & & & & & & & \\
\end{tabular}

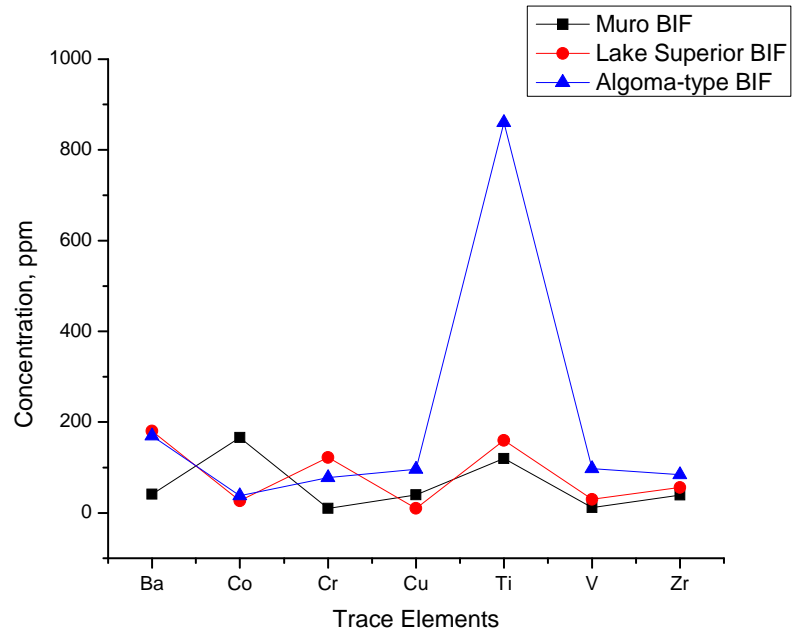

Figure 10. Spider diagram comparing the trace element composition of Muro BIF and those of Lake Superior-type and Algoma-type BIFs.

These differences in the trace element concentrations may be attributed to the level of detrital material (clay constituents) in the original iron-formation. The $\mathrm{Al}_{2} \mathrm{O}_{3}$ content, which is a measure of the detrital dilution of iron-formations [20], is less in the Muro oxide facies (0.28\%) than in the Lake Superior oxide facies (3.06\%) (Table 2). The geochemistry of the various trace elements is summarised below.
Chromium and Niobium: Chromium concentration is low being in the range of $10-19 \mathrm{ppm}$ in the oxide facies and $12-24 \mathrm{ppm}$ in the carbonate facies. Compared with those of the Lake Superior-type and the Algoma-type iron-formations (Table 4) the $\mathrm{Cr}$ concentration is particularly low but it is closer in value to those of the Minas Gerais itabirite and the Orissa BIF. Such a low $\mathrm{Cr}$ concentration has been reported in Swedish iron ores and BIF deposited as oxidates in sedimentary environments $[17,21]$. Niobium concentration is low (5 - $8 \mathrm{ppm})$ but its distrbution tends to be uniform in both the oxide and carbonate facies. Because this element has not been determined in most iron-formations it is impossible to compare its level of concentration in the Muro oxide facies with those of other iron-formations.

Vanadium: Vanadium distribution pattern in the Muro iron-formation is facies dependent. The vanadium content of the oxide facies is low (average $12 \mathrm{ppm}$ ) while that of the carbonate facies is comparatively higher (average $100 \mathrm{ppm}$ ). A similar relationship exists in the Lake Superior-type BIF (Table 4).

Yttrium: Yttrium concentration is very low. If one sample that gave an anomalous value of $45 \mathrm{ppm}$ is ignored, all the remaining samples contain little (less than $5 \mathrm{ppm}$ ) or no yttrium at all.

Zirconium, Uranium and Thorium: Zirconium content is relatively low and its distribution is somewhat uniform in both the oxide and carbonate facies with its 
concentration ranging from 36 - 43 ppm. The average $\mathrm{Zr}$ contents of the Muro oxide-facies (39 ppm) and carbonate-facies (42 ppm) are less than those of their corresponding facies in the Lake Superior-type and Algomatype iron-formations. Since the distribution of this element is attributed to provenance rather than to sorting of sediments [17], its low level of concentration therefore indicates that the iron-formation is derived from low $\mathrm{Zr}$ source materials. This possibility excludes igneous derivation of the iron-formation but favours a sedimentary origin.

Uranium: Uranium concentration is very low (ranging from 6 - $12 \mathrm{ppm}$ ) with a uniform distribution pattern as both oxide and carbonate facies display similar average U contents (8 and 9 ppm, respectively).

Thorium: Thorium occurs in generally very low concentrations (5 - $12 \mathrm{ppm}$ ) with most samples being below the detection limit (5 ppm).

Cobalt and Nickel: Cobalt content of the Muro ironformation is high, varying from 128 - 194 ppm, and it contrasts greatly with low contents of the Lake Superiortype, Algoma-type and Orissa BIF as well as the Minas Gerais itabirite (Table 4). In the Muro iron-formation the cobalt concentration of the oxide facies (142 - 194 ppm) is higher than that of the carbonate facies (128 - 154 ppm). Nickel concentration is generally very low in the Muro iron-formation, ranging from $<10-26 \mathrm{ppm}$. It is particularly low in the oxide facies ( $<10 \mathrm{ppm})$.

Copper, Lead and Zinc: The Muro iron-formation is relatively enriched in copper but is impoverished in lead and zinc. $\mathrm{Cu}$ distribution tends to be facies dependent with lower concentration in the oxide facies (average 40 ppm) compared with its higher content in the carbonate facies (average $304 \mathrm{ppm}$ ). A similar relationship has been found in the Isua BIF in Greenland [22].

Barium, Strontium and Rubidium: Both barium and strontium exhibit a similar distribution pattern. The concentrations of both elements are relatively high in the carbonate facies and are comparatively much less in the oxide facies (Table 3). The sympathetic behaviour of the two elements is attributable to the fact that Sr associates with $\mathrm{Ba}$ and $\mathrm{Ca}$ in nature [17]. Sr content is generally low in the Muro iron-formation being in the range of 16 $37 \mathrm{ppm}$. The average Sr contents of both the oxide and carbonate facies compare favourably with those of the Lake Superior-type BIF but are appreciably less than those of the Algoma-type BIF (Table 3). On the other hand, the Ba content of the carbonate facies is very high (614 - $1144 \mathrm{ppm}$ ) with an average of 924 ppm while those of the oxide facies is not only low but highly variable (9 - 93 ppm). Rubidium is strongly depleted in the iron-formation, its value being below the detection limit (5 ppm) of the analytical equipment

Generally, the trace element concentrations of the
Muro oxide facies is similar to those of the Lake Superior oxide facies except for the much lower contents of $\mathrm{Ba}$ and $\mathrm{Cr}$, and much higher contents of Co in the Muro BIF (Figure 10). On the other hand, the trace element contents of the Muro oxide facies differ from those of the Algoma oxide facies (Figure 10). The Muro BIF has significantly lower contents of $\mathrm{Ba}, \mathrm{Cr}, \mathrm{Cu}, \mathrm{Ti}, \mathrm{V}$ and $\mathrm{Zr}$ compared to the Algoma-type BIF.

\section{Mineral Chemistry}

Electron microprobe analysis of hematite in the oxide facies of Muro Iron Formation is presented while that of the carbonate mineral in the carbonate facies is presented. The hematite contains only minor amounts of $\mathrm{MnO}$, $\mathrm{Al}_{2} \mathrm{O}_{3}$ and $\mathrm{SiO}_{2}$, while the carbonate is dominantly rhodochrosite with minor amounts of magnesia and siderite. Both analyses reveal the minor importance of manganese in the iron formation [cf 23].

\section{Summary and Conclusions}

The major and trace element distribution patterns of the Muro BIF are essentially similar to those of the Lake Superior-type BIFs as described by $[12,15,17]$. The observed trace element distribution and abundance patterns in the iron-formation also lend support to the shallow water sedimentary deposition of the iron-formation. Lower concentrations of $\mathrm{Cr}$, $\mathrm{Ti}$, $\mathrm{Ni}$ and $\mathrm{Zr}$, (which have a strong igneous affinity) in the Muro Iron-Formation than in the Algoma analogue indicate a sedimentary origin of the iron-formation. Paucity of trace elements especially of $\mathrm{Ba}, \mathrm{Co}, \mathrm{Ca}, \mathrm{Mn}, \mathrm{Ni}$ and $\mathrm{Pb}$ in the iron-formation suggests shallow water deposition $[15,17]$. According to [17] very low concentrations of $\mathrm{V}, \mathrm{Cr}, \mathrm{Zr}, \mathrm{Ni}$ and $\mathrm{Cu}$ in $\mathrm{BIF}$ indicate low temperature precipitation under sedimentary conditions. The Muro BIF contains particularly low contents of these elements (see Table 3), thus supporting the low temperature deposition of the iron-formation in a sedimentary environment.

The weak positive correlation of $\mathrm{TiO}_{2}$ with $\mathrm{Al}_{2} \mathrm{O}_{3}$ as well as their very low concentrations in the Muro BIF suggests only very minor terrigeneous contribution to its source materials (silica and iron) [24,25]. This observation is supported by the scarcity of silicate minerals in the mineral assemblage. Silica was deposited as chert as revealed by the occurrence of jasper and metachert in the iron-formation. The presence in the jasper of siliceous spheroidal structures which are ascribed to biogenic origin [26] suggests some biological contribution to the silica content of the BIF.

Muro Iron-Formation, which is made up of predominant oxide facies and subordinate carbonate facies, is of the Lake Superior-type. This is demonstrated by its similarity in both lithological association and geochemistry to 
the Lake Superior-type iron-formations. These similarities suggest common depositional environments and source materials.

\section{Acknowledgements}

We wish to express our profound gratitude to Professor Bob Martins of the Department of Geological Sciences, McGill University, Montreal, Canada for permitting the analysis of the samples to be done in the geochemical laboratories of his department. We are also grateful to colleagues in the Nigerian Geological Survey Agency and the Obafemi Awolowo University, Ile-Ife, Nigeria for their logistic support. The study was largely funded by the Federal University of Technology, Akure through the University Research Grant number URG 87-88/03.

\section{REFERENCES}

[1] H. L. James, "Sedimentary Facies of Iron-Formations," Economic Geology, Vol. 49, No. 3, 1954, pp. 235-293. doi:10.2113/gsecongeo.49.3.235

[2] J. A. Adekoya, "The Geology of Banded Iron-Formations in the Precambrian Basement Complex of Northern Nigeria,” Ph. D. Dissertation, University of Ibadan, Ibadan, 1991.

[3] J. A. Adekoya and B. O. Oladeji, "Geological and Structural Setting of the Muro Hills Banded Iron-Formation, Plateau State, Nigeria,” Journal of Mining and Geology, Vol. 22, 1985, p. 161.

[4] E. O. G. Muotoh, P. O. Oluyide, A. U. Okoro and O. Mogbo, “The Muro Hills Banded Iron-Formation,” In: P. O. Oluyide, W. C. Mbonu, A. E. Ogezi, I. G. Egbuniwe, A. C. Ajibade and A. C. Umeji, Eds., Precambrian Geology of Nigeria, Geological Survey of Nigeria, Kaduna, 1988, pp. 219-227.

[5] L. O. Anike, A. C. Umeji and A. C. Onyeagocha, "Geology and Geochemistry of the Muro Banded Iron-Formation, S. W. Plateau State, Nigeria,” Journal of Mining and Geology, Vol. 17, 1990, pp. 21-26.

[6] L. O. Anike, A. C. Umeji and I. P. Orajaka, "Geology of Precambrian Banded Iron Formation from Muro Hill, Nigeria,” Economic Geology, Vol. 88, No. 5, 1993, pp. 1237-1241. doi:10.2113/gsecongeo.88.5.1237

[7] M. A. Rahaman, "Recent Advances in the Study of the Basement Complex of Nigeria," In: P. O. Oluyide, W. C. Mbonu, A. E. Ogezi, I. G. Egbuniwe, A. C. Ajibade and A. C. Umeji, Eds., Precambrian Geology of Nigeria, Geological Survey of Nigeria, Kaduna, 1988, pp. 11-43.

[8] A. C. Ajibade and J. B. Wright, "Structural Relationships in the Schist Belts of Northwestern Nigeria,” In: P. O. Oluyide, W. C. Mbonu, A. E. Ogezi, I. G. Egbuniwe, A. C. Ajibade and A. C. Umeji, Eds., Precambrian Geology of Nigeria, Geological Survey of Nigeria, Kaduna, 1988, pp. 103-110.

[9] H. L. James, "Precambrian Iron-Formations: Nature, Origin, and Mineralogic Evolution from Sedimentation to Metamorphism,” In: K. H. Wolf and C. V. Chilingarian,
Eds., Developments in Sedimentology, Vol. 47, 1992, pp. 543-589.

[10] G. J. S. Govett, “Origin of Banded Iron-Formation,” Geological Society of America Bulletin, Vol. 77, No. 11, 1966, pp. 1191-1212. doi:10.1130/0016-7606(1966)77[1191:OOBIF]2.0.CO;2

[11] M. N. Gole, “Archean Banded Iron-Formations, Yilgarn Block, Western Australia,” Economic Geology, Vol. 76, No. 7, 1981, pp. 1954-1974. doi:10.2113/gsecongeo.76.7.1954

[12] G. A. Gross, "Geochemistry of Iron-Formation in Canada,” In: J.-J. Chauvel, C. Yugi, E. M. El-Shazly, G. A. Gross, K. Laajoki, M. S. Markov, K. L. Rai, V. A. Stulchikov and S. S. Augustithis, Eds., Ancient Banded iron Formations (Regional Representations), Theophrastus, Athens, 1990, pp. 3-26.

[13] B. Mason, "Principles of Geochemistry," 3rd Edition, John Wiley \& Sons, New York, 1966.

[14] H. Lepp and S. S. Goldich, "Origin of the Precambrian Iron-Formation,” Economic Geology, Vol. 59, No. 6, 1964, pp. 1025-1060. doi:10.2113/gsecongeo.59.6.1025

[15] T. Majumder, K. L. Chakraborty and A. Bhattacharya, "Geochemistry of Banded Iron-Formation of Orissa, India,” Mineralium Deposita, Vol. 17, No. 1, 1982, pp. 107118. doi:10.1007/BF00206379

[16] G. A. Gross and C. R. Macleod, “A Preliminary Assessment of the Chemical Composition of Iron-Formations in Canada," Canadian Miner-alogist, Vol. 18, 1980, pp. 223 $-229$.

[17] K. L. Rai and P. R. Paul, "Geochemistry of Banded IronFormation, Iron Ores and Associated Lithologies from Jamda-Koira Valley of Bihar, India,” In: J.-J. Chauvel, C. Yugi, E. M. El-Shazly, G. A. Gross, K. Laajoki, M. S. Markov, K. L. Rai, V. A. Stulchikov and S. S. Augustithis, Eds., Ancient Banded iron Formations (Regional Representations), Theophrastus, Athens, 1990, pp. 311326.

[18] A. F. Trendall and J. G. Blockley, “The Iron-Formations of the Hamersley Group, Western Australia, with Special Reference to the Associated Crocidolite,” Geological Survey of Western Australia, Perth, 1990.

[19] H. L. James, "Data of Geochemistry," 6th Edition, US Geological Survey, Professional paper 440-W, 1966.

[20] R. L. Stanton, “Ore Petrology,” McGraw Hill Book Co., New York, 1972.

[21] S. Landergren, "On the Geochemistry of Sweedish Iron Ore and Associated Rocks," Sveriges Geologika Undersokning, Vol. 42, No. 5, 1948, pp .1-182.

[22] P. W. U. Appel, "Geochemistry of the Early Archean Isua Iron-Formation, West Greenland,” In: P. W. U. Appel and G. L. La Berge, Eds., Precambrian Iron-Formations, Theophrastus, Athens, 1987, pp. 31-68.

[23] A. Mucke, “The Nigerian Manganese-Rich Iron-Formations and Their Host Rocks-From Sedimentation to Metamorphism,” Journal of African Earth Sciences, Vol. 41, No. 5, 2005, pp. 407-436. doi:10.1016/j.jafrearsci.2005.07.003

[24] C. A. Spier, S. M. B. de Oliveira, A. N. Sial and F. J. Rios, 
"Geochemistry and Genesis of the Banded Iron Formations of the Caue Formation, Quadrilatero Ferrifero, Minas Gerais, Brazil,” Precambrian Research, Vol. 152, No. 3-4, 2007, pp.170-206.

doi:10.1016/j.precamres.2006.10.003

[25] E. Pecoits, M. K. Gingras, M. E. Barley, A. Kappler, N. R. Posth and K. O. Konhauser, "Petrography and Geochemistry of of the Dales Gorge Banded Iron Formation: Par- agenetic Sequence, Source, and Implications for PaleoOcean Chemistry,” Precambrian Research, Vol. 172, No. 1-2, 2009, pp. 163-187. doi:10.1016/j.precamres.2009.03.014

[26] J. A. Adekoya, "Relict Sedimentary Features in Metamorphosed Proterozoic Banded Iron-Formations, Northern Nigeria,” Nigerian Journal of Science, Vol. 36, No. 2, 2002, pp. 129-138. 